\title{
Mengatasi perilaku kerja kontraproduktif melalui peran integratif politik organisasional dan kecerdasan emosional pada era revolusi industri 4.0
}

\author{
Sunargo $^{1^{*}}$; Dwi Hastuti \\ ${ }^{1}$ Fakultas Ilmu Sosial dan Humaniora, Universitas Putera Batam, Batam \\ ${ }^{2}$ Fakultas Ekonomi dan Bisnis, Universitas Jambi, Jambi \\ *E-mail korespondensi: sunargo@puterabatam.ac.id
}

\begin{abstract}
Counterproductive work behavior is a common phenomenon that is a problem in human resources. Such work behavior can be considered through situational and individual factors. The workplace environment situation that contains political activity and individual ability who have emotional intelligence can determine work behavior. This study examines the influence of perceived organizational politics on counterproductive work behavior and examines the role of moderation on that effect. The test was carried out using data of 200 employee respondents who worked at companies in the Batam industrial area. Results of the study using hierarchical regression analysis show that perceived organizational politics have a positive and significant effect on counterproductive work behavior. Furthermore, emotional intelligence can mitigate counterproductive work behavior caused by organizational political situations. This research provides practical benefits in overcoming the problem of counterproductive work behavior.
\end{abstract}

Keywords: Perceived organizational politics, Emotional intelligence, Counterproductive work behavior

\begin{abstract}
Abstrak
Perilaku kerja kontraproduktif merupakan fenomena umum yang menjadi masalah dalam sumber daya manusia. Perilaku tersebut dapat dipertimbangkan melalui faktor situasional dan individual. Situasi lingkungan tempat kerja yang mengandung unsur politik dan kemampuan individu yang memiliki kecerdasan emosional dapat menentukan perilaku kerja. Penelitian ini menguji pengaruh politik organisasional persepsian terhadap perilaku kerja kontraproduktif, serta menguji peran moderasi pada pengaruh tersebut. Pengujian dilakukan menggunakan data responden 200 karyawan yang bekerja pada perusahaan di kawasan industri Batam. Dengan menggunakan analisis regresi bertingkat hasil penelitian menunjukkan bahwa politik organisasional persepsian berpengaruh positif dan signifikan pada perilaku kerja kontraproduktif. Selanjutnya, kecerdasan emosional dapat memitigasi perilaku kerja kontraproduktif yang disebabkan oleh situasi politik organisasional. Penelitian ini memberikan manfaat secara praktis dalam mengatasi masalah perilaku kerja kontraproduktif.
\end{abstract}

Kata kunci: Politik organisasional persepsian, Kecerdasan emosional, Perilaku kerja kontraproduktif

\section{PENDAHULUAN}

Kemajuan sektor industri di Indonesia memiliki peran penting dalam melakukan peningkatan pertumbuhan ekonomi dan pembangunan nasional. Dampaknya dapat 
memberikan kontribusi pada penyerapan tenaga kerja, pengentasan kemiskinan, pengurangan pengangguran dan pemerataan pendapatan masyarakat. Dalam konsideran undang-undang perindustrian nomor 3 tahun 2014 menjelaskan bahwa melalui pembangunan industri sebagai motor penggerak ekonomi memerlukan dukungan kompentensi sumber daya yang tangguh dalam rangka pembangunan nasional pada bidang ekonomi untuk menghasilkan sistem perekonomian yang kuat. Perlunya pengelolaan keseluruhan sumberdaya secara optimal, termasuk sumber daya manusia yang tercermin melalui perilaku kerja agar dapat meningkatkan produktifitas kerja.

Persaingan global pada era revolusi industri 4.0 memerlukan kemampuan sumber daya manusia untuk memberikan kontribusi terhadap pencapaian tujuan organisasi atau perusahaan. Berbagai fenomena perilaku kerja perlu menjadi perhatian dalam pengelolaan sumber daya manusia yang dapat menentukan produktifitas kerja dan keunggulan kompetitif. Perilaku kerja negatif yang terjadi pada berbagai sektor industri dapat menurunkan produktifitas dan menghambat dalam pencapaian keberhasilan perusahaan. Hal ini menjadi tantangan pengelolaan sumber daya manusia untuk mengatasi perilaku kerja negatif tersebut yang dikenal dengan istilah perilaku kerja kontraproduktif pada berbagai sektor industri.

Pembahasan perilaku kerja kontraproduktif menjadi perhatian akademisi maupun praktisi karena perilaku tersebut dapat menyebabkan konsekuensi negatif dan membahayakan produktifitas perusahaan (Whelpley \& McDaniel, 2016). Perilaku tersebut secara umum dapat terjadi dalam bentuk penyelewengan aset, menunda pekerjaan, memperpanjang waktu istirahat, datang terlambat bekerja, mengabaikan isntruksi pimpinan dan perilaku kerja merugikan lainnya (Chang \& Smithikrai, 2010). Munculnya perilaku kerja kontraproduktif perlu diketahui penyebabkan karena dapat menimbulkan masalah serius bagi perusahaan maupun pekerja lainnya.

Penyebab perilaku kerjakontraproduktif dapat dipahami melalui faktor situasional dan individual. Karyawan dapat mempersepsikan adanya situasi lingkungan perusahaan terkait dengan kepentingan karyawan atau perusahaan sebagai pertimbangan untuk menentukan perilaku kerja selanjutnya. Pertimbangan faktor tersebut dikenal dengan istilah politik organisasional. Lingkungan kerja perusahaan yang mengandung aktivitas politik dapat dipandang sebagai bentuk keterampilan atau taktik pengelolaan dalam rangka meraih kepentingan personal semata. Hal ini dapat menimbulkan ketidakadilan organisasional, meningkatkan tekanan dan ketidakpuasan kerja serta perilaku kerja disfungsional (Bedi \& Schat, 2013., Cohen, 2015., Meisler \& Vigoda-Gadot, 2014).

Sementara itu, aspek individual karyawan terkait dengan kemampuan menggunakan emosional yang dapat menghasilkan penalaran kognitif dalam merespon situasi atau fenomena yang terjadi pada lingkungan perusahaan (Vough \& Caza, 2016). Kemampunan emosional melibatkan penyesuaian, pemahaman, pengaturan, pengendalian dan penggunaan emosional diri dan orang lain yang disebut dengan istilah kecerdasan emosional (Salovey \& Mayer, 1990). Karyawan yang memiliki kecerdasan emosional dapat menggunakan kemampuannya dalam menanggapi aktivitas politik dengan menunjukkan perilaku kerja yang positif dan inovatif, serta meningkatkan perilaku kerja produktif (De Clercq et al., 2014, Matta et al., 2014).

Penelitian Meisler \&Vigoda-Gadot (2014) menunjukkan bahwa perilaku mengabaikan sebagai bentuk perilaku kontraproduktif dipengaruhi oleh kecerdasan emosional dan dimediasi oleh politik organisasional persepsian secara positif dan signifikan. Sementara itu, penelitian Latifah \& Wulansari (2017) memiliki temuan yang berbeda bahwa kecerdasan emosional berpengaruh negatif dan tidak signifikan terhadap politik organisasional. Penelitian ini berupaya menjembatani bahwa kecerdasan emosional yang tinggi dapat menurunkan pengaruh positif politik organisasional persepsian terhadap perilaku kerja disfungsional yang dijelaskan melalui mekanisme moderasi. 
Selanjutnya, penelitian ini dilakukan dengan menetapkan beberapa tujuan. Pertama, menguji pengaruh politik organisasinal persepsian terhadap perilaku kerja kontraproduktif. Kedua, penelitian ini bertujuan untuk menguji peran kecerdasan emosional memoderasi pengaruh politik organisasional persepsian terhadap perilaku kerja kontraproduktif. Hasil temuan penelitian ini diharapkan dapat memberikan beberapa manfaat. Pertama, penelitian ini memberikan penjelasan bahwa munculnya perilaku kerja kontraproduktif melalui pertimbangan integrasi faktor kontekstual dan individual sehingga dapat memberikan temuan yang menarik. Kedua, memberikan penjelasan dan memperkaya literasi manajemen sumber daya manusia pada aspek perilaku kerja kontraproduktif. Kedua, mengetahui peran kecerdasan emosional pada pengaruh politik organisasional persepsian terhadap perilaku kerja kontraproduktif.

\section{TINJAUAN PUSTAKA}

\section{Politik organisasional persepsian dan perilaku kerja kontraproduktif}

Politik organisasional persepsian dapat dipahami sebagai penilaian subjektif karyawan terkait dengan lingkungan kerja sejauh mana dipengaruhi perilaku mementingkan diri sendiri (Ferris \& Hochwarter, 2011). Adanya aktivitas politik organisasional mencerminkan keseluruhan karakter menguntungkan atau merugikan organisasional (Kiewitz et al, 2009). Penelitian Ferris \& Hochwarter (2011) telah menemukan bahwa politik organisasional dapat mengakibatkan pengaruh negatif dan meningkatkan ketidakpastian sehingga melemahkan kinerja dan produktifitas kerja.

Perilaku kerja kontraproduktif merupakan setiap tindakan yang dilakukan karyawan secara sadar dengan melanggar norma-norma signifikan dan legitimasi organisasi (Bennett \& Robinson, 2000). Perilaku tersebut dapat dijumpai secara umum pada berbagai bentuk perusahaan misalnya, demonstrasi anarkis, mengabaikan kerja dan instruksi pimpinan, konflik interpersonal, melakukan aktivitas tidak berkaitan dengan pekerjaan, serangan fisik atau verbal dan perilaku merugikan lainya. Fox \& Spector (2005) dalam penelitian menunjukkan bahwa perilaku kerja kontraproduktif memiliki konsekuensi negatif yang dapat terjadi pada berbagai tingkat organisasi. Munculnya perilaku kerja tersebut secara kontekstual dapat berasal dari situasi lingkungan kerja yang menekankan pada kepentingan sepihak sebagai bentuk politik organisasional persepsian.

Situasi lingkungan perusahaan yang mengandung aktivitas politik organisasional memberikan sinyal kepada karyawan bahwa perusahaan tidak memperhatikan kesejahteraan, tidak menghargai kontribusi, dan menjalankan kepentingan sepihak. Persepsi kayaran terhadap aktivitas politik dapat menurunkan kepuasan kerja, meningkatkan ketegangan, intensi keluar, dan perilaku mengabaikan kinerja (Chang et al., 2009; Latifah \& Wulansari, 2017; Meisler \& Vigoda-Gadot, 2014). Melalui penjelasan tersebut dapat dirumuskan hipotesis sebagai berikut:

Hipotesis 1: Politik Organisasional Persepsian berpengaruh positif terhadap perilaku kerja kontraproduktif.

\section{Peran kecerdasan emosional sebagai pemoderasi}

Perilaku kerja dapat tergantung dari fakor kemampuan individual untuk memahami, mengatur, mengendalikan dan menggunakan emosional (Meisler \& Vigoda-Gadot, 2014; Weick et al., 2005). Ketika karyawan memersepsikan bahwa perusahaan terdapat aktivitas politik, karyawan lebih cenderung mencari pemaknaan atas situasi tersebut melalui kemampuan emosional sehingga memungkinkan untuk menemukan pemahaman terhadap peristiwa yang terjadi. Karyawan melakukan pemrosesan interpretasi melalui kecerdasan emosional sebagai pemoderasi hubungan antara politik organisasional persepsian terhadap reaksi yang akan ditimbulkannya berupa perilaku kerja. Dengan 
demikian, interpretasi atas situasi politik organisasional persepsian akan tergantung pada kemampuan karyawan dalam memahami, mengatur, mengendalikan dan menggunakan emosional.

Ketika karyawan menemukan kesenjangan hasil yang tidak sesuai dengan harapan, maka karyawan memiliki kecenderungan untuk mencari penjelasan dan pemaknaan yang akan menentukan tindakan terhadap situasi atau peristiwa yang terjadi (Weick et al., 2005). Karyawan merasakan politik organisasional akan melibatkan kemampuan emosional dalam memberikan pemahaman atau pemaknaan pada situasi tersebut yang dapat menentukan respon perilaku kerja karyawan. Karyawan melakukan pemrosesan informasi sosial dalam memahami situasi atau peristiwa yang terjadi yang dapat membentuk perilaku kerja karyawan (Salancik \& Pfeffer, 1978). Karyawan yang mampu mengelola emosional akan lebih mudah memeroleh dan menggunakan informasi sebagai pertimbangan dalam melakukan sebuah tindakan.

Ketika karyawan merasakan bahwa lingkungan perusahaan terdapat aktivitas politik, karyawan akan melibatkan kecerdasan emosional untuk memberikan pemaknaan terhadap situasi atau peristiwa tersebut. Karyawan yang memiliki kecerdasan emosional yang rendah akan memiliki kecenderungan yang lemah untuk melakukan pengendalian atas situasi yang terjadi, sehingga dapat menguatkan pengaruh positif politik organisasional persepsian terhadap perilaku kerja kontraproduktif. Begitupula sebaliknya, ketika karyawan memiliki kecerdasan emosional yang tinggi maka karyawan akan menggunakan kecerdasan emosional untuk memahami aktivitas politik sehingga dapat melemahkan pengaruh positif politik organisasional persepsian terhadap perilaku kerja kontraproduktif. Berdasarkan uraian tersebut, maka hipotesis yang dibangun adalah: Hipotesis 2: Kecerdasan emosional memoderasi pengaruh positif politik organisasional persepsian terhadap perilaku kerja kontraproduktif.

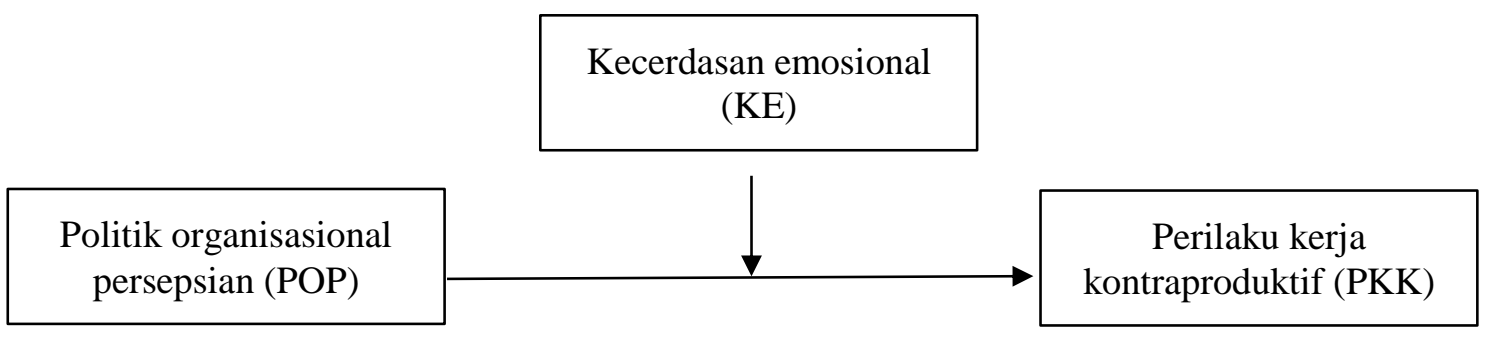

Gambar 1. Kerangka konseptual model penelitian

\section{METODE}

Motode yang digunakan pada penelitian ini merupakan bentuk kuantitatif yang dirancang untuk menguji hipotesis dengan mengukur pengaruh variabel bebas, terikat dan moderasi. Penelitian ini menggunakan unit analisis pada tingkat individu untuk mengetahui bagaimana pengaruh variabel perilaku kerja karyawan dalam perusahaan.

\section{Partisipan dan prosedur}

Penelitian ini menggunakan pengambilan sampel sebanyak 200 responden secara nonprobability sampling dimana besaran terpilihnya responden dari suatu populasi tidak diketahui secara pasti (Cooper \& Schindler, 2014). Sampel tersebut ditentukan menggunakan purposive sampling dengan teknik judgement sampling melalui beberapa 
pertimbangan atau kriteria tertentu. Pertama, responden merupakan karyawan yang bekerja pada perusahaan di kawasan industri Batam yang merupakan salah satu kota besar di Indonesia sebagai penggerak perekonomian melalui aktivitas industri. Kedua, responden merupakan karyawan yang telah memiliki masa kerja minimal 2 tahun dimana responden dianggap telah mampu memahami pertukaran yang berlangsung selama hubungan kerja dan memengaruhi keputusan dalam menunjukkan perilaku kerja.

Data diperoleh menggunakan metode survei dimana terdapat instrumen penelitian berupa kuesioner yang dirancang secara cermat, sistematis dan terstruktur sehingga memungkinkan responden untuk menentukan alternatif jawaban. Kuesioner disebarkan secara self administered survey questionnaire pada satu titik waktu tertentu. Pengisian kuesioner dilakukan secara sukarela dan tidak memberikan hadiah dalam bentuk apapun atas partisipasi responden. Selain itu, peneliti berupaya menghidari tekanan atau rasa khawatir dan menghasilkan data pengisian kuesioner secara lengkap dan akurat melalui jaminan anonimitas dan kerahasiaan data responden.

\section{Instrumen penelitian}

Politik Organisasional Persepsian (POP) merupakan penilaian individu terhadap situasi dan kondisi lingkungan kerja mengandung unsur politik dimana mencerminkan ketidakadilan dan kepentingan diri sendiri (Vigoda, 2002). Pengukuran variabel POP menggunakan instrumen yang telah dikembangkan oleh Vigoda (2002) yang terdiri dari 6 (enam) butir pertanyaan menggunakan penilaian 5 poin skala likert (mulai $1=$ sangat tidak setuju, sampai dengan 5 = sangat setuju).

Kecerdasan Emosional (KE) merupakan kemampuan individu dalam melakukan penggunaan, penilaian, dan pengaturan emosional diri sendiri maupun orang lain (Wong \& Law, 2002). Pengukuran variabel KE menggunakan instrumen yang telah di kembangkan oleh Wong \& Law (2002) yang terdiri dari 12 butir pertanyaan menggunakan penilaian 5 poin skala likert (mulai 1 = sangat tidak setuju, sampai dengan 5 = sangat setuju).

Perilaku Kerja Kontraproduktif (PKK) merupakan tindakan secara sadar yang dilakukan oleh karyawan dengan menunjukkan perilaku yang melanggar norma-norma signifikan organisasional (Bennett \& Robinson, 2000). Pengukuran variabel PKK menggunakan instrumen yang terdiri dari 12 butir pertanyaan menggunakan penilaian 5 skala frekuensi (mulai $1=$ tidak pernah, sampai dengan $5=$ sangat sering).

Variabel kontrol yang menjadi pertimbangan dalam memengaruhi variabel POP, KE dan PKK. Pertama, jenis kelamin pria daripada wanita cenderung lebih agresif dan memiliki intensi yang kuat untuk melakukan perilaku membalas (Bowling \& Burns, 2015). Kedua, usia responden (dalam tahun) bahwa seiring dengan bertambahnya usia memiliki kemunkinan yang rendah untuk melakukan perilaku menyimpang (Berry et al., 2007). Ketiga, masa kerja responden (dalam tahun) dimana semakin rendah masa kerja memiliki potensi lebih kuat terlibat pada perilaku kerja disfungsional (Robinson \& O'Leary-Kelly, 1998). Keempat, pendidikan formal yang semakin tinggi daripada rendah memungkinkan karyawan untuk melakukan pengelolaan dan pengaturan emosional yang lebih baik melalu tindakan yang produktif.

\section{HASIL DAN PEMBAHASAN}

Hasil pengumpulan data melalui survei sebanyak 200 responden telah mengisi kuesioner secara lengkap sehingga dapat digunakan sebagai data dalam penelitian ini. Dalam mengelola, menguji dan menganalisis data menggunakan alat bantu aplikasi program perangkat lunak SPSS versi 25 . Berdasarkan data responden dapat diketahui terdapat karyawan laki-laki $(63,7 \%)$ dan perempuan $(36,3 \%)$ dimana bekerja pada perusahaan manufaktur $(38,3 \%)$, perdagangan $(27,9 \%)$, keuangan $(17,9 \%)$, pariwisata $(8,7 \%)$ dan industri lainnya $(7,2 \%)$. Responden memiliki masa kerja $8-10$ tahun $(31,3 \%)$, 
5-7 tahun (25,2\%), 2-4 tahun (23,9\%) dan masa kerja > 10 tahun $(19,6 \%)$. Adapun latar belakang pendidikan responden lulusan Sekolah Menengah Atas (38,9), diploma $(22,6 \%)$, sarjana $(29,2 \%)$, dan pendidikan master $(9,3 \%)$. Sementara itu, usia responden dimulai dari rentang 20-29 tahun (42,2\%), 30-39 tahun (19,4\%), 40-49 tahun (20,1\%) dan diatas 50 tahun $(18,3 \%)$.

\section{Pengujian instrumen}

Pengujian instrumen penelitian menggunakan Confirmatory Factor Analysis (CFA) dengan pertimbangan factor loadings. Analisis menunjukkan bahwa nilai KMO-MSA adalah 0,973 dimana data telah memiliki syarat kecukupan sampel. Selanjutnya nilai BTS signifikan 0,000 yang menunjukkan bahwa data telah memenuhi syarat dalam analisis faktor dan memiliki korelasi antar variabel. Hasil analisis data menunjukkan bahwa secara keseluruhan instrumen pengukuran berjumlah 34 indikator dapat diyatakan valid (factor loadings $>0,65$ ). Selanjutnya pengujian reliabilitas menggunakan nilai koefisien Cronbach alpha. Instrumen penelitian pada variabel POP, KE dan PKK memiliki koefisien secara berturut adalah 0,902., 0,953., dan 0,971 dimana telah memiliki reliabilitas yang baik.

\section{Statistik deskriptif}

Berdasarkan statistik deskriptif pada Tabel 1 dapat diketahui bahwa responden yang bekerja pada sektor industri di Batam menunjukkan adanya politik organisasional yang cukup tinggi $(3,56)$, adanya perilaku kerja kontraproduktif $(2,49)$ dan tingkat kecerdasan emosional responden cukup tinggi $(4,33)$ pada berbagai bidang pekerjaan. Karakteristik responden sebagai variabel kontrol memiliki korelasi positif terhadap variabel KE, serta memiliki korelasi negatif terhadap variabel POP dan variabel PKK. Selanjutnya, variabel POP memiliki korelasi positif dan signifikan dengan variabel PKK. Sementara itu, variabel KE memiliki korelasi negatif dengan variabel POP dan PKK.

Tabel 1. Statistik deskriptif dan korelasi variabel

\begin{tabular}{lrcccccccc}
\hline \multicolumn{1}{c}{ Variabel } & M & SD & $\mathbf{1}$ & $\mathbf{2}$ & $\mathbf{3}$ & $\mathbf{4}$ & $\mathbf{5}$ & $\mathbf{6}$ & $\mathbf{7}$ \\
\hline Jenis Kelamin & 0,44 & 0,34 & 1 & & & & & & \\
Usia & 2,86 & 1,26 & $0,154^{*}$ & 1 & & & & & \\
Pendidikan & 2,97 & 1,73 & $0,403^{+}$ & $0,523^{+}$ & 1 & & & & \\
Masa Kerja & 1,43 & 0,81 & $0,593^{+}$ & $0,729^{+}$ & $0,443^{+}$ & 1 & & & \\
POP & 3,56 & 1,13 & $-0,344^{+}$ & $-0,313^{+}$ & $-0,359^{+}$ & $-0,378^{+}$ & 1 & & \\
KE & 4,33 & 1,03 & $0,301^{+}$ & $0,337^{+}$ & $0,316^{+}$ & $0,348^{*}$ & $-0,012^{+}$ & 1 & \\
PKK & 2,49 & 0,89 & $-0,459^{+}$ & $-0,524^{+}$ & $-0,771^{+}$ & $-0,492^{+}$ & $0,582^{*}$ & $-0,513^{+}$ & 1 \\
\hline
\end{tabular}

*Korelasi signifikan pada tingkat 0,05 (2-tailed). ${ }^{+}$. Korelasi signifikan pada tingkat 0,01 (2-tailed)

Sumber: Data diolah, 2019

\section{Analisis data}

Pengujian hipotesis pada penelitian ini menggunakan model analisis regresi bertahap (hierarchical regression analysis). Adapun tahapan tesebut diawali dengan melakukan analisis variabel kontrol, berikutnya variabel POP, kemudian variabel KE sebagai variabel pemoderasi, dan pada tahap selanjutnya melakukan analisis interaksi POP dan KE. Sebelum analisis tahapan tersebut, variabel independen dan pemoderasi dilakukan mean-centering untuk menghindari masalah multikolinearitas sehingga memperoleh hasil yang lebih baik pada pengaruh interaksi (Aiken \& West, 1991). Tabel 4.2 berikut ini menyajikan hasil uji hipotesis secara keseluruhan. 
Tabel 2. Analisis regresi moderasi bertingkat

\begin{tabular}{lcrrr}
\hline \multicolumn{1}{c}{ Prediktor } & $\boldsymbol{\beta}$ & $\boldsymbol{\beta}$ & \multicolumn{1}{c}{$\boldsymbol{\beta}$} & \multicolumn{1}{c}{$\boldsymbol{\beta}$} \\
\hline Jenis kelamin & $-0,305^{\ddagger}$ & $-0,219^{\ddagger}$ & $-0,171^{\ddagger}$ & $-0,135^{\ddagger}$ \\
Usia & $-0,471^{\ddagger}$ & $-0,409^{\ddagger}$ & $-0,253^{\ddagger}$ & $-0,246^{\ddagger}$ \\
Pendidikan & $-0,360^{\ddagger}$ & $-0,324^{\ddagger}$ & $-0,285^{\ddagger}$ & $-0,277^{\ddagger}$ \\
Masa kerja & $-0,231^{\ddagger}$ & $-0,216^{\ddagger}$ & $-0,172^{+}$ & $-0,134^{*}$ \\
POP & & $0,257^{+}$ & $0,233^{\ddagger}$ & $0,213^{\ddagger}$ \\
KE & & & $-0,391^{\ddagger}$ & $-0,277^{\ddagger}$ \\
POP x KE & & & & $-0,340^{\ddagger}$ \\
$R^{2}$ & 0,724 & 0,741 & 0,824 & 0,853 \\
$F$-ratio & $158,442^{\ddagger}$ & $137,571^{\ddagger}$ & $162,745^{\ddagger}$ & $158,939^{\ddagger}$ \\
\hline
\end{tabular}

Keterangan: ${ }^{*} p<0,05 ;{ }^{+} p<0,01 ;{ }^{*} p<0,001$

Sumber: Data diolah, 2019

Pengujian hipotesis 1 dilakukan dengan menganalisis regresi variabel POP terhadap variabel PKK dimana menunjukkan pengaruh positif dan signifikan $(\beta=0,257 ; p<0,01)$. Selain itu, analisis tersebut menunjukkan bahwa variabel KE memiliki pengaruh negatif dan signifikan terhadap PKK $(\beta=-0,391 ; p<0,001)$. Pengujian hipotesis tersebut dilakukan setelah memasukkan beberapa variabel kontrol meliputi jenis kelamin $(\beta=-$ $0,305 ; p<0,001)$, usia $(\beta=-0,471 ; p<0,001)$, pendidikan $(-0,360 ; p<0,001)$, dan masa kerja $(\beta=-0,231 ; p<0,001)$. Melalui tabel analisis regresi juga dapat diketahui bahwa variabel POP menjelaskan varians PKK sebesar 74,1\% $\left(R^{2}=0,741\right)$, dan secara simultan menjelaskan perubahan pada PKK $(F=137,571 ; p<0,001)$. Dengan demikian dapat disimpulkan bahwa hipotesis 1 didukung secara statistik.

Pengujian hipotesis selanjutnya melakukan analisis regresi interaksi variabel POP dan KE terhadap variabel PKK. Hasil analis regresi tersebut mengindikasikan bahwa terdapat pengaruh interaksi negatif dan signifikan $(\beta=-0,340 ; p<0,001)$. Hal ini mengandung interpretasi bahwa pengaruh positif variabel POP terhadap PKK akan menjadi semakin lemah ketika KE tinggi, begitu pula sebaliknya. Gambar 4.1 menyajikan grafis simple slope yang dapat digunakan untuk memudahkan interpretasi hasil analisis regresi. Melalui gambar tersebut dapat dipahami bahwa kemiringan garis regresi pada KE tinggi lebih tajam dibandingkan dengan garis regresi pada KE rendah. Hal ini menunjukkan bahwa KE rendah daripada tinggi dapat menguatkan pengaruh positif POP terhadap PKK. Dengan demikian, hasil analisis regresi menunjukkan dukungan hipotesis 2.

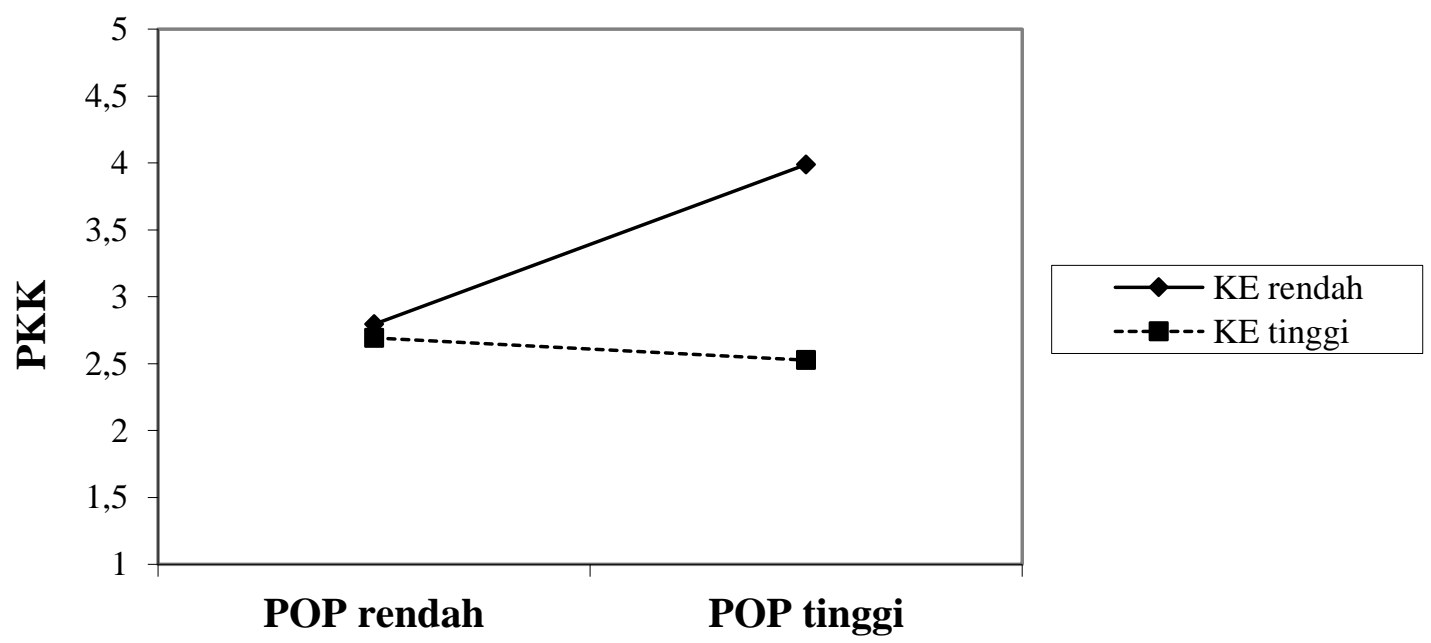

Gambar 2. Hasil analisis regresi 


\section{Implikasi kebijakan}

Peneliti ini berupaya mengungkap beberapa temuan menarik yang dapat memberikan kontribusi dalam mengatasi PKK pada sektor industri. Investigasi temuan tersebut dilakukan melalui pengujian faktor kontekstual dan individual yang dapat menentukan PKK. Perilaku kerja karyawan dapat tergantung dari situasi politik organisasional dan pemaknaan atas situasi tersebut menggunakan kemampuan emosional. Selai itu, karakteristik responden meliputi jenis kelamin, usia, pendidikan dan masa kerja juga dapat menentukan PKK yang disebabkan oleh POP dan KE. Karakteristik repsonden pria dengan usia yang relatif muda, serta pendidikan formal dan masa kerja yang lebih rendah akan lebih memiliki kecenderungan untuk menunjukkan perilaku PKK. Dengan demikian, dapat dipahami bahwa melalui pertimbangan situasi lingkungan kerja dan karakteristik individu termasuk kemampuan emosional dapat memberikan penjelasan atas munculnya perilaku PKK.

Penelitian ini menemukan bahwa karyawan yang bekerja pada perusahaan di berbagai sektor industri kota Batam dinilai jarang terlibat perilaku PKK. Situasi POP yang cukup tinggi dapat menentukan perilaku PKK pada perusahaan tersebut. Karyawan melibatkan pemaknaan atau pemahaman menggunakan kecerdasan emosional terhadap situasi POP yang terjadi pada lingkungan perusahaan. Hal ini yang dapat menentukan perilaku PKK jarang terjadi pada perusahaan tersebut. Dengan demikian, peran moderasi KE menjadi pertimbangan penting dalam mengatasi perilaku PKK yang disebabkan oleh situasi POP pada lingkungan perusahaan.

\section{KESIMPULAN DAN SARAN}

\section{Kesimpulan}

Sesuai dengan tujuan penelitian yang telah dibahas pada latar belakang penelitian ini berupaya memberikan kontribusi untuk mengatasi perilaku PKK. Secara umum perilaku tersebut dapat terjadi pada berbagai sektor industri, dalam hal ini penelitian menggunakan data responden pada kawasan industri di Batam. Penelitian ini menunjukkan bahwa POP dan KE dapat menjadi faktor penentu terhadap perilaku PKK. Perusahaan perlu memperhatikan POP dan KE agar dapat meningkatkan produktifitas dan keunggulan bersaing.

Pada era revolusi industri 4.0 dimana terdapat pengembangan teknologi dan informasi yang diterapkan pada berbagai aktivitas industri menjadi salah satu pilar dalam pertumbuhan ekonomi. Dalam menjawab tantangan tersebut tentu harus didukung dengan kekuatan sumber daya manusia sebagai penggerak untuk meningkatkan produktifitas segala bidang. Perusahaan pada berbagai sektor industri harus melakukan terobosan baru dengan mendorong tindakan yang kreatif dan inovatif kepada pekerja atau karyawan sebagai sumber daya manusia potensial. Pertimbangan aspek situasional lingkungan kerja dan individual karyawan dapat menentukan produktifitas kerja.

Berbagai dinamika perusahaan dan persaingan kerja pada tingkat kepentingan tertentu memungkinkan terjadinya politik organisasional. Karyawan yang merasakan adanya situasi tersebut akan mempersepsikan ketidakadilan dan dapat menurunkan kepuasan kerja, serta menunjukkan perilaku kerja yang tidak produktif. Hal ini dapat menimbulkan kondisi yang tidak menguntungkan bagi perusahaan maupun karyawan lainnya. Perusahaan perlu mengatasi perilaku PKK dengan cara memastikan bahwa lingkungan tidak mengandung karakter negatif pada politik organisasional yang mengutamakan kepentingan tertentu untuk memperoleh keuntungan secara sepihak.

Selain itu, perusahaan dapat memitigasi perilaku PKK dengan cara mengembangkan kemampuan emosional karyawan, sehingga memiliki kercerdasan 
emosional yang tinggi. Karyawan yang memiliki kemampuan KE yang tinggi dapat mengatasi perilaku PKK yang disebabkan oleh situasi POP. Sementara itu, karyawan yang memiliki KE yang rendah dapat menguatkan pengaruh positif situasi POP terhadap perilaku PKK. Dengan demikian, peran KE mampu memberikan pemahaman atau pemaknaan atas situasi yang terjadi sehingga dapat menentukan terbentuknya perilaku kerja. Meskipun penelitian ini berupaya memberikan hasil yang optimal, namun memiliki beberapa keterbatasan yang harus diperhatikan pada penelitian berikutnya. Pertama, sifat sampel tidak mampu menjelaskan generalisasi temuan secara umum.

\section{Saran}

Saran pada penelitian selanjutnya dapat menggunakan sampel pada sektor lainnya, misalnya sektor publik. Kedua, penelitian ini menggunakan data cross-sectional yang mungkin dapat menimbulkan masalah common method variance. Saran pada penelitian selanjutnya dapat mengumpulkan data pada sumber berbeda melalui pengumpulan data pada waktu berbeda atau jangka waktu tertentu.

\section{DAFTAR PUSTAKA}

Aiken, L. S., \& West, S. G. (1991). Multiple regression: Testing and interpreting interactions. Newburry Park, CA: Sage.

Bedi, A., \& Schat, A. C. (2013). Perceptions of Organizational Politics: A Meta-Analysis of It's Attitudinal, Health, and Behavioural Consequences. Canadian Psychology/Psychologie Canadienne, 54(4), 246-259.

Bennett, R. J., \& Robinson, S. L. (2000). Development of A Measure of Workplace Deviance. Journal of Applied Psychology, 85(3), 349-360.

Berry, C. M., Ones, D. S., \& Sackett, P. R. (2007). Interpersonal Deviance, Organizational Deviance, and Their Common Correlates: A Review and MetaAnalysis. Journal of Applied Psychology, 92(2), 410-424.

Bowling, N. A., \& Burns, G. N. (2015). Sex as A Moderator of The Relationships Between Predictor Variables and Counterproductive Work Behavior. Journal of Business and Psychology, 30(1), 193-205.

Chang, K., \& Smithikrai,C. (2010). Counterproductive Behaviour at Work: An Investigation Into Reduction Strategies. The International Journal of Human Resource Management, 21(8), 1272-1288.

Cohen, A. (2015). Fairness in the Workplace. UK: Palgrave Macmillan.

Cooper, D. R., \& Schindler, P. S. (2014). Business Research Methods (12th ed.). New York: The McGraw-Hill Companies.

De Clercq, D., Bouckenooghe, D., Raja, U., \& Matsyborska, G. (2014). Unpacking The Goal Congruence-Organizational Deviance Relationship: The Roles of Work Engagement and Emotional Intelligence. Journal of Business Ethics, 124(4), 695711.

Ferris, G. R., \& Hochwarter, W. A. (2011). Organizational Politics. In S. Zedeck, H. Aguinis, W. Cascio, M. Gelfand, K. Leong, S. Parker, \& J. Zhou (Eds.), Handbook of Industrial and Organizational Psychology (435-459). Washington, DC: American Psychologycal Association.

Fox, S., \& Spector, P. E. (2005). Counterproductive Work Behavior: Investigations Of Actors and Targets. Washington, DC: American Psychologycal Association.

Junaidi,J., Amri, A., \& Hardiani, H. (2014). Potensi Klaster Agroindustri Usaha Mikro Kecil dan Menengah di Provinsi Jambi. Jurnal Perspektif Pembiayaan dan Pembangunan Daerah, 2(1), 9-20 
Kiewitz, C., Restubog, S. L. D., Zagenczyk, T., \& Hochwarter, W. (2009). The Interactive Effects of Psychological Contract Breach and Organizational Politics on Perceived Organizational Support: Evidence From Two Longitudinal Studies. Journal of Management Studies, 46(5), 806-834.

Latifah, L., \& Wulansari, N. A. (2017). Pengaruh Kecerdasan Emosional pada Perilaku Lalai dengan Menggunakan Persepsi Politik Organisasional sebagai Variabel Pemediasi. Management Analysis Journal, 6(3), 351-362.

Matta, F. K., Erol- Korkmaz, H. T., Johnson, R. E., \& Biçaksiz, P. (2014). Significant Work Events and Counterproductive Work Behavior: The Role of Fairness, Emotions, and Emotion Regulation. Journal of Organizational Behavior, 35(7), 920-944.

Meisler, G., \& Vigoda-Gadot, E. (2014). Perceived Organizational Politics, Emotional Intelligence and Work Outcomes: Empirical Exploration of Direct and Indirect Effects. Personnel Review, 43(1), 116-135.

Robinson, S. L., \& O'Leary-Kelly, A. M. (1998). Monkey See, Monkey Do: The Influence of Work Groups on The Antisocial Behavior of Employees. Academy of Management Journal, 41(6), 658-672.

Salancik, G. R., \& Pfeffer, J. (1978). A Social Information Processing Approach to Job Attitudes and Task Design. Administrative Science Quarterly, 23(2), 224-253.

Salovey, P., \& Mayer, J. D. (1990). Emotional Intelligence. Imagination, Cognition and Personality, 9(3), 185-211.

Vigoda, E. (2002). Stress- Related Aftermaths To Workplace Politics: The Relationships Among Politics, Job Distress, and Aggressive Behavior in Organizations. Journal of Organizational Behavior, 23(5), 571-591.

Vough, H. C., \& Caza, B. B. (2016). Where do I go from here? Sensemaking and The Construction of Growth-Based Stories in the Wake of Denied Promotions. Academy of Management Review, 42(1), 103-128.

Weick, K. E., Sutcliffe, K. M., \& Obstfeld, D. (2005). Organizing and The Process of Sensemaking. Organization science, 16(4), 409-421.

Whelpley, C. E., \& McDaniel, M. A. (2016). Self-Esteem and Counterproductive Work Behaviors: A Systematic Review. Journal of Managerial Psychology, 31(4), 850863.

Wong, C. S., \& Law, K. S. (2002). The Effects of Leader and Follower Emotional Intelligence on Performance and Attitude: An Exploratory Study. The Leadership Quarterly, 13(3), 243-274.

Zamzami, Z., \& Hastuti, D. (2018). Determinan Penerimaan Daerah dan Pertumbuhan Ekonomi Terhadap Pengembangan Ekonomi Kreatif di Provinsi Jambi. Jurnal Paradigma Ekonomika, 13(1), 37-45 